\title{
Masaisko ingen effekt mot ryggsmerter
}

\section{Bruk av masaisko gir ikke mindre korsryggssmerter enn vanlige joggesko, viser engelsk studie.}

Sko med avrundet såle, såkalte masaisko, er blitt et populært hjelpemiddel for å lindre ryggsmerter. Men virker de? I en randomisert studie er effekten av masaisko sammenliknet

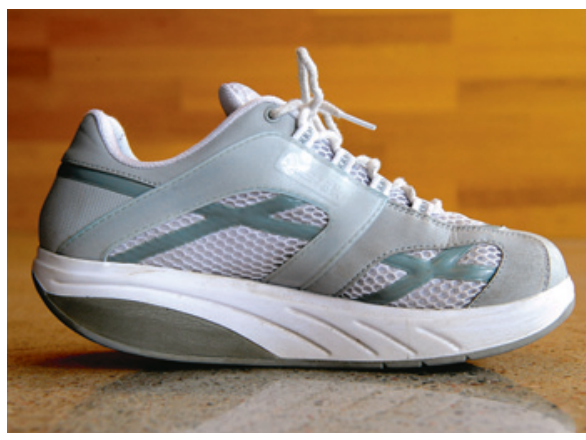

Foto: Scanpix Sweden med effekten av vanlige joggesko hos pasienter med kroniske korsryggssmerter (1).

Studien omfattet 115 personer som skulle bruke masaisko eller vanlige joggesko mens de sto eller gikk, i minst to timer hver dag i ett år. Selvrapportert funksjonsnivå og smerter ble registrert flere ganger i løpet av perioden.

Etter 12 måneder rapporterte deltakerne $\mathrm{i}$ begge grupper bedret funksjonsnivå og mindre smerter. Det var ingen signifikante forskjeller mellom dem som brukte masaisko og dem som brukte vanlige joggesko når alle deltakerne var med i analysene. Blant deltakerne som opplevde ryggsmerter ved gange eller når de sto, rapporterte brukerne av masaisko i gjennomsnitt 2 poengs bedring i funksjonsnivå $(95 \% \mathrm{KI} 0,4-3,6 ; \mathrm{p}<0,05)$, mens de som brukte vanlige joggesko rapporterte 4,4 poengs bedring ( $95 \% \mathrm{KI} 2,8-6,6$; $\mathrm{p}<0,05)$.

- Masaisko kom på markedet for ca. ti år siden og skulle bidra til naturlige bevegelser og hjelpe på plager fra fot, kne, hofte og rygg, sier seksjonsoverlege Jens Ivar Brox ved Ortopedisk avdeling, Oslo universitetssykehus. - Jeg fikk selv et par av importøren, men erfarte at de egnet seg best som isolasjon mot isen når jeg fulgte min sønn på bandytrening.

- Resultatene av denne studien er ikke overraskende. Markedsføring skaper forventninger når det gjelder skotøy og annen behandling. Gevinsten er ofte størst før virkningen er undersøkt i godt designede studier, sier Brox.

\section{Matilde Risopatron Berg}

Tidsskriftet

\section{Litteratur}

1. MacRae CS, Lewis JS, Shortland AP et al. Effectiveness of rocker sole shoes in the management of chronic low back pain: a randomized clinical trial. Spine 2013; 38: 1905-12.

\section{Depresjon hos ungdom kan forebygges}

\section{Gruppeterapi kan forebygge depresjon hos ungdommer med deprimerte foreldre, viser studie i USA.}

Ungdommer med deprimerte foreldre har stor risiko for selv å oppleve depresjon. En amerikansk forskergruppe har undersøkt om gruppebasert kognitiv atferdsterapi kan forebygge depresjon hos slike ungdommer (1). Behandlingen besto av åtte ukentlige gruppebehandlingsmøter etterfulgt av seks månedlige møter. 316 ungdommer $i$ alderen 13-17 år ble randomisert til enten gruppebehandling eller vanlig oppfølging. Foreldrene hadde enten pågående eller tidligere depressiv lidelse.

I løpet av vel 2 1/2 år utviklet $37 \%$ av ungdommene $\mathrm{i}$ behandlingsgruppen en depresjon, mot $48 \%$ i kontrollgruppen. Dette tilsvarer at ti ungdommer måtte behandles for å forebygge ett tilfelle av depresjon (number needed to treat). Forskjellen mellom gruppene var statistisk signifikant kun der foreldrene hadde tidligere, og ikke pågående, depresjon.

- Hovedfunnene i denne studien er spen- nende og aktuelle, og resultatene setter familieperspektivet på dagsorden, sier Ole Rikard Haavet, fastlege og førsteamanuensis ved Avdeling for allmennmedisin, Universitetet $\mathrm{i}$ Oslo. - Det er viktig å merke seg at barn og ungdom av deprimerte foreldre er en høyrisikogruppe når det gjelder depresjon.

- Mange fastleger har god kjennskap til sine pasienters familieforhold og bør være ekstra årvåkne overfor barn og ungdom som har foreldre med psykiske lidelser. Stadig flere fastleger har videreutdanning i kognitiv atferdsterapi, og dette bør komme disse ungdommene til gode, sier Haavet.

\section{Sigurd Høye \\ Tidsskriftet}

\section{Litteratur}

1. Beardslee WR, Brent DA, Weersing VR et al. Prevention of depression in at-risk adolescents: longer-term effects. JAMA Psychiatry 2013; 70: 1161-70.

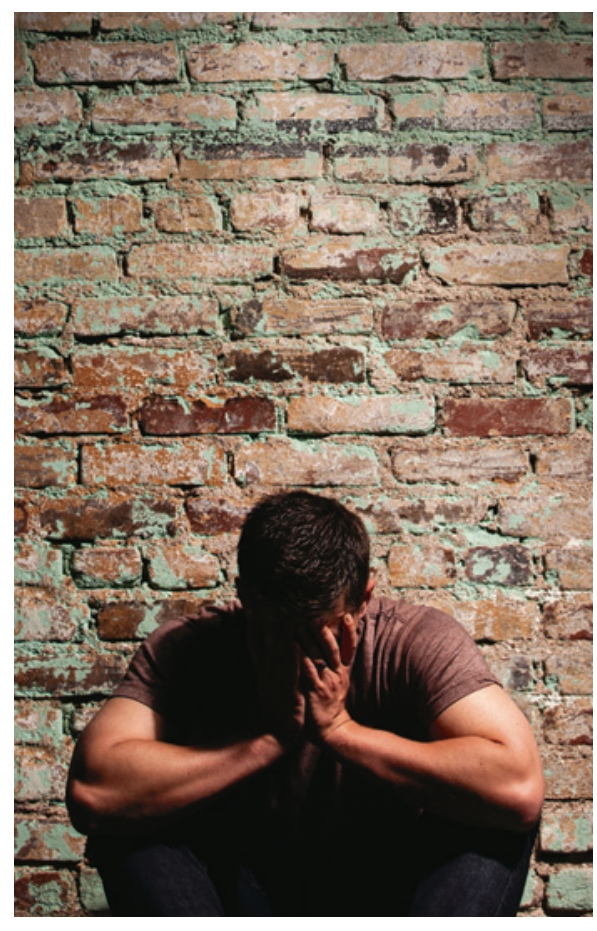

Foto: Thinkstock 